Article

\title{
Surviving after Cross-Border Acquisitions: How Business Relatedness, Host Country Experience, and Cultural Distance Affect Acquired Firms
}

\author{
Ilaria Galavotti *, Daniele Cerrato $\$$ and Franca Cantoni \\ Department of Economic and Social Sciences, Università Cattolica del Sacro Cuore, Via Emilia Parmense 84, \\ 29122 Piacenza, Italy; daniele.cerrato@unicatt.it (D.C.); franca.cantoni@unicatt.it (F.C.) \\ * Correspondence: ilaria.galavotti@unicatt.it
}

Received: 18 July 2020; Accepted: 17 August 2020; Published: 19 August 2020

check for updates

\begin{abstract}
The effects of cross-border acquisitions on the survival of target firms is attracting increasing academic interest. Specifically, whether cross-border acquisitions may hamper target firms' performance or enhance their sustainable competitiveness represents a highly debated research question. Building on the knowledge-based perspective of mergers and acquisitions, this paper directs attention to absorptive capacity and investigates the likelihood of survival of target firms acquired by foreign investors. In particular, it examines the role played by three potential antecedent conditions of an acquiring firm's absorptive capacity on the probability of the target firm's survival: (a) The business relatedness between acquirer and target, (b) previous experience of the acquirer in the host country, and (c) the cultural distance between the countries of the acquiring and acquired firms. Based on a sample of 396 Italian firms acquired by foreign multinationals, results suggest that target firms are more likely to survive in case the acquirer benefits from previous country-level experience and in case of business relatedness, while the cultural distance between the home country of the acquiring firm and Italy does not prove to be a significant determinant of survival versus mortality of acquired subsidiaries. Overall, our analysis confirms that context familiarity, in terms of both country and business contexts, plays a fundamental role in determining the sustainable competitiveness of acquired firms.
\end{abstract}

Keywords: cross-border acquisitions; target firms' survival; business relatedness; host country experience; cultural distance

\section{Introduction}

The effect of foreign investments on the sustainable development of subsidiaries is a central theme in the international business literature, e.g., [1-3], where several studies have examined the survival [1,3,4] and longevity [5] of foreign subsidiaries. However, while a host of contributions have explored the destiny of foreign affiliates in the context of international joint ventures, e.g., [6-9], the sustainability of firms' competitive advantages in the specific domain of cross-border acquisitions is comparatively still underdeveloped $[10,11]$. Indeed, the literature on cross-border acquisitions has mostly examined the effects of acquisitions on acquiring firms' performance, regarded through the lenses of value creation for acquirers' shareholders, using either accounting-based (e.g., [12-15]) or financial measures (e.g., $[16,17])$. Therefore, the investigation of the outcomes on target firms, especially in terms of survival, is still quite unexplored and appears to offer vibrant lines of inquiry. As testified by the increasing number of studies on this topic especially in recent years, e.g., [10,11,18-20], the exploration of the potential antecedents that may affect the survival of foreign acquired affiliates seems a particularly fertile research avenue. 
One of the most widely adopted arguments in this research domain is that the survival and longevity of acquired subsidiaries is closely related to the extent to which key organizational capabilities and knowledge bases are mutually transferred between parent and subsidiary. The role of knowledge transfer has represented a topical research theme in the literature on acquisitions, especially in the context of cross-border acquisitions, where uncertainty, information asymmetry [21], and liability of foreignness [22] may jeopardize the realization of expected synergies and the ability of acquiring firms to exploit and extend their knowledge and competence bases abroad [23,24]. The knowledge-based view has thus gained an increasingly popular place within academic conversations, since knowledge transfer has appeared as a sine-qua-non condition enabling the realization of the synergistic potential that motivates and justifies the acquisition, e.g., [25-27]. Knowledge is in fact the most important strategic resource for a firm's competitive advantage [28-30], and the transfer of knowledge plays a crucial role for value creation in acquisitions, e.g., [26]. The knowledge-based view of mergers and acquisitions is in tight connection with the capabilities-based view [31] and with the increasingly flourishing literature on dynamic capabilities [32]. Within this framework, absorptive capacity represents a key capability that enables firms to assimilate and reconfigure knowledge and capabilities [30,33].

Prior research has highlighted that two key elements shape a firm's absorptive capacity: Complementary knowledge [34] and prior related experience [35]. In an acquisition context, the existence of compatible knowledge between acquiring and target firms may derive from similar business domains, i.e., may be driven by the business relatedness between acquirer and target [27]. Similarly, because cross-border acquisitions are inherently characterized by unfamiliarity with the target context, the acquirer's previous experience in the host country may substantially enhance its absorptive capacity: Extant research has highlighted that learning about host country conditions helps the firm to develop social knowledge [36], to obtain local legitimacy [37], and to more effectively transfer strategic resources and organizational practices [3], while also developing new specific resources that can be transferred to the subsidiary [10]. Scholars, however, have also claimed that cultural distance plays an important role in shaping the firm's ability to understand which key capabilities need to be transferred [38] and in promoting learning $[39,40]$. Our framework therefore explores the role played by cultural distance as an additional potential antecedent of a firm's absorptive capacity.

With absorptive capacity being acknowledged as a critical dynamic capability affecting the success of acquisitions [25], this paper examines the effect played by three potential antecedent conditions that may shape firms' ability to transfer and absorb new knowledge and thus the destiny of acquired firms: (a) The business relatedness between acquirer and target, (b) the acquiring firm's previous host country experience, and (c) the cultural distance between home and host country.

Both acquirer-to-target business relatedness and the acquirer's host country experience may hence foster the firm's absorptive capacity and its ability to adapt and transfer knowledge and strategic resources to the foreign subsidiary, thus increasing its sustainable competitive advantage and chances of survival. This study therefore aims at establishing a link between these three potential antecedents of absorptive capacity and the sustainable competitiveness of the acquired firms in terms of likelihood of survival.

We test our hypotheses on a sample of 396 cross-border acquisitions in Italy executed between 2005 and 2015. Our results confirm that the survival of foreign subsidiaries is positively associated with familiarity at both business and context level, gained through both acquirer-to-target relatedness and the acquirer's previous experience in Italy as host country. The effect played by cultural distance does not prove to be significant and potential explanations are discussed.

The paper is organized as follows. In the next section, we provide a review of the literature and develop our hypotheses; then, the methodology is outlined with a focus on the peculiarities of the selected research context, the criteria for sample selection and data collection, and the measurement of our variables. In the fourth section, results of the empirical analysis are presented and then followed by a discussion. Finally, the paper concludes by offering implications and suggesting future research avenues. 


\section{Literature Review and Hypotheses}

In an acquisition context, ideally, the combined knowledge pool of the two formerly independent firms should be greater than the two knowledge stocks separately for the acquisition to generate synergies [25]. However, the extent to which the value of the combined knowledge bundles of acquiring and target firms is greater than the values of the two knowledge stocks taken independently is a function of the ability to transfer knowledge. Knowledge transfer depends on two key organizational dynamic capabilities, i.e., absorptive capacity and combinative capability.

The notion of dynamic capability can be broadly defined as the ability to systematically reconfigure strategic, organizational, and operating routines to realize new resources combinations [32,33,41]. While combinative capability is strongly related to social capital theory [42] and depends on the opportunity, motivation, and ability to share knowledge, absorptive capacity is a dynamic capability that is embedded in a firm's processes and knowledge base.

In Cohen and Levinthal's [43] theorization, absorptive capacity is defined as the capacity to assimilate new knowledge. In their reconceptualization, Zahra and George [44] take a broader perspective that goes beyond assimilation and define absorptive capacity as the "set of organizational routines and processes by which firms acquire, assimilate, transform, and exploit knowledge to produce a dynamic organizational capability" (p. 186).

Prior research has highlighted two key elements that shape a firm's absorptive capacity: Prior related experience [35] and complementary knowledge [34]. Prior related experience is embedded in the repertoire of organizational routines that shape the firm's knowledge base upon which it develops its absorptive capacity [43]. The second determinant is the extent to which the firms have similar knowledge bases [34,45].

The theoretical perspective of subsidiary evolution posits that, although the acquiring firm is responsible for the allocation of resources and activities to the acquired company, it is often the acquired firm itself that owns the critical resources and competencies for its own development and longevity [10]. Because, after an acquisition, the target firm is expected to adopt and absorb the know-how of the acquiring company [2], the ability of the acquirer to transfer its own knowledge becomes decisive. Within this framework, we suggest that three antecedent conditions may shape the extent to which knowledge can be transferred and, thus, make the competitiveness of target firms more sustainable over time: The degree of business relatedness between acquirer and target, the host country experience of the acquiring company, and the cultural distance between acquirer and target.

\subsection{The Effect of Acquirer-To-Target Business Relatedness}

Business relatedness, i.e., relatedness at the parent-subsidiary level, has been extensively studied for its role on subsidiary performance and survival, e.g., [4,46,47]. The so-called 'relatedness hypothesis', according to which acquisitions in a related business tend to outperform acquisitions in an unrelated business, has been central to a plethora of academic contributions falling within the broader research area addressing the diversification-performance relationship, e.g., [48-50]. In particular, relatedness has been regarded as a fundamental premise to the strategic fit between acquirer and target, defined as "the degree to which the target firm augments or complements the parent's strategy and thus makes identifiable contributions to the financial and non-financial goals of the parent" [51] (p. 146).

In the context of cross-border acquisitions, in which the information asymmetry and the uncertainty deriving from liability of foreignness may challenge the realization of expected synergies, the choice to diversify has been acknowledged as a relevant issue affecting the performance and survival of foreign subsidiaries [4]. Because the more a firm departs from the current business, the greater the exposure to uncertainty [52], the challenges inherent in the acquisition process may exponentially increase due to the fact that the risks associated with the entry in a foreign country are coupled with risks associated with the entry in a new business [53]. In such circumstances, unrelated industries are less likely to share similarities in procedures, cultures, and dominant logics [54] and the acquirer is therefore less likely to possess relevant resources and competencies that may be transferred to the foreign subsidiary $[4,55]$. 
The lack of familiarity with the target's business may also potentially generate dysfunctionalities during the integration process by injecting attitudes that threaten the creation of an atmosphere for knowledge and capability transfer [31], for instance by misapplying management systems through the imposition of the parent firm's practices onto the newly acquired subsidiary [51].

On the contrary, at greater business similarity between acquirer and target, potential synergies at market, technological, and product-level may possibly increase thanks to the broader set of resources and capabilities that can be transferred to the new subsidiary [56]. In addition, this knowledge base may be more effectively transferred, with positive effects on the sustainable development of target firms. Indeed, similar business backgrounds imply similar knowledge domains between acquirer and target $[27,34,35]$. This in turn increases the knowledge compatibility between acquirer and target [27]. Since Cohen and Levinthal's [43] theorization of absorptive capacity, it has been acknowledged that, although acquisitions virtually allow to significantly depart from existing resources, it is almost impossible to acquire new knowledge if the firm does not already possess some related knowledge. Therefore, the existence of compatible knowledge bases deriving from similar business domains may represent a crucial antecedent condition that determines the absorptive capabilities of firms in cross-border acquisitions [27]. As related business backgrounds imply that the "cognitive structures" and the business logics of acquirer and target are potentially more aligned, parent-subsidiary business relatedness may facilitate the transfer of knowledge $[57,58]$ and of the parent's firm-specific advantages [59-61] with positive effects on the subsidiary performance $[47,59,60]$. Our paper extends these arguments and suggests that, because at greater relatedness not only is the acquirer better able to transfer its knowledge to the subsidiary but the subsidiary is also better able to leverage on the acquirer's firm-specific advantages [47], business relatedness may strengthen the sustainable competitive advantage of target firms and thus increase their likelihood of survival. Our arguments suggest that to delve deeper into the survival of acquired firms, it is important to take into account the distinction between those acquisitions in which the two firms operate in the same business versus those in which the two firms are not related to one another in terms of business activity. We indeed contend that this difference may potentially explain variations in the survival of acquired firms. The following hypothesis may therefore be formulated:

Hypothesis 1 (H1). In cross-border acquisitions, the business relatedness between acquirer and target has a positive effect on the survival of the acquired firm.

\subsection{The Effect of Acquirer's Host Country Experience}

A key antecedent of absorptive capacity is the firm's past experience [44]. The exposure to knowledge sources in the form of environmental scanning [44], interorganizational relations [34], and learning-by-doing mechanisms [62] contributes to the creation of routines and shapes managerial cognition, which in turn influence the firm's ability to manage knowledge [63].

Extant research acknowledges that host country experience represents a crucial element in international expansion processes [64]. Literature has examined the effect played by local experience on both investment choices, e.g., [39,65] and performance, e.g., [66]. Cross-border expansion is characterized by liability of foreignness and relational hazards [67], that typically result in a competitive disadvantage with respect to local incumbents [22]. This disadvantage can however be overcome or, at least, mitigated, by accumulating host country experience: Learning about host country conditions helps the firm to develop social knowledge [36], to obtain local legitimacy [37], and to more effectively transfer strategic resources and organizational practices [3], while also developing new specific resources that can be transferred to the subsidiary [10]. Familiarity with the host country gained through prior experience in the country therefore represents a key element that may reduce the firm's liability of foreignness and operational difficulties in the host market, thus alleviating its competitive disadvantage [3]. Examining the survival and the performance of 3080 subsidiaries of 641 Japanese multinationals, Delios and Beamish [3] find a positive relationship between previous host country 
experience and subsidiary survival. Similarly, building on the hazard rate model to analyze the likelihood of survival of foreign investments in the United States in the pharmaceutical and computer industries between 1974-1989, Li [9] highlights that exit rates are higher when the investor does not have previous experience in the United States and when the commitment of resources to the subsidiary is not continued over time through additional investments. Overall, it has therefore been argued that the rate of survival [9], as well as longevity and evolution [1,5,10], increase when the acquirer has host country experience.

In contrast, in the absence of previous experience in the target country, acquirers are more exposed to risks arising from the information asymmetry [21] and from the hampered transfer of knowledge $[35,68]$. Building on these arguments, we suggest that host country experience may foster the firm's absorptive capacity and its ability to adapt and transfer knowledge and strategic resources to the foreign subsidiary, thus increasing its sustainable competitive advantage and likelihood of survival. We hence argue that having or not having experience in the host country does carry an explanatory power on variations in the survival of acquired subsidiaries. This leads us to formulate the following hypothesis:

Hypothesis 2 (H2). In cross-border acquisitions, acquirer's experience in the target country has a positive effect on the survival of the acquired firm.

\subsection{The Effect of Cultural Distance}

The exploration of cultural differences in cross-border mergers and acquisitions has received significant academic attention, whereby international business scholars have increasingly emphasized that distance actually represents a multi-dimensional construct [69]. The important role of cultural distance in determining the extent to which firm-specific advantages have to be adapted [70], and in shaping how the acquiring firm perceives the target company and the target context is vastly recognized [71]. However, cultural distance is a complex notion that has been approached in a variety of ways, including Kogut and Singh's [21] measure based on Hofstede's cultural dimensions and the Globe project [72]. In view of the multifaceted nature of this construct, we follow prior literature [73] and consider cultural distance through the lenses of Hofstede's multiple dimensions, namely power distance, individualism, masculinity, uncertainty avoidance, long-term orientation, and indulgence.

The influence of cultural distance on cross-border acquisitions performance still represents an unsolved puzzle. Research has indeed yielded mixed empirical findings that reveal ambiguous implications on whether cross-cultural differences are detrimental or may have synergistic effects [74]. Several studies have suggested a negative relationship between cultural distance and post-acquisition performance because the inevitable cultural collisions [51,75] may hamper an effective socio-cultural integration [76], resulting in value destruction for the shareholders of the acquiring firm [60]. Cultural distance has also been regarded as one of the components of country risk as it significantly impacts the possible benefits that may be accrued when investing in a given country [77].

Because acquisitions represent a preferential way for accessing external resources and know-how, and because the extent to which they may be attained is subject to valuation barriers and possible opportunistic behaviors [78], difficulties may exponentially increase as the distance and the geographic dispersion of resources increase as well [79], thus generating obstacles to the effective valuation of potential targets along with organizational resistance during the post-acquisition phases [69]. For instance, Popli et al. [80] examined the relationship between cultural distance and the likelihood of abandoning a cross-border acquisition and found that it is reduced when the acquirer has experience in the same country or in a culturally similar country.

Building on the theoretical perspective of subsidiary evolution, Uhlenbruck [10] suggests that cultural distance may reduce the possibility of the target firm to access resources and know-how of the acquirer. Observing a sample of 170 cross-border acquisitions in transition economies in Europe over the period 1990-1993, Uhlenbruck [10] argues that the potential for learning and knowledge transfer 
along with the possibility to nurture the resource base of the acquired firm and to effectively integrate it are reduced at increasing cultural distance, thereby hampering the subsidiary's evolution over time [2].

Scholars, however, have also claimed that cultural distance plays an important role in shaping the firm's ability to understand which key capabilities need to be transferred [38] and in promoting learning [39,40]. Building on these arguments, for instance, Ahammad et al. [26] have hypothesized that cultural distance may provide opportunities to both acquirer and target to leverage cultural resources in order to complement each other. Despite the leaning opportunities that cultural distance may provide, it may also engender opportunism and lead to higher transaction costs [81,82], which may jeopardize acculturation and the transfer of knowledge and capabilities [5,83]. In line with these arguments, we suggest that cultural distance constrains the potential sustainable development of target firms and hence undermines the likelihood of survival of foreign acquired subsidiaries. Such considerations lead us to the following hypothesis:

Hypothesis 3 (H3). In cross-border acquisitions, cultural distance between acquirer and target has a negative effect on the survival of the acquired firm.

The conceptual model and hypotheses are reported in Figure 1.

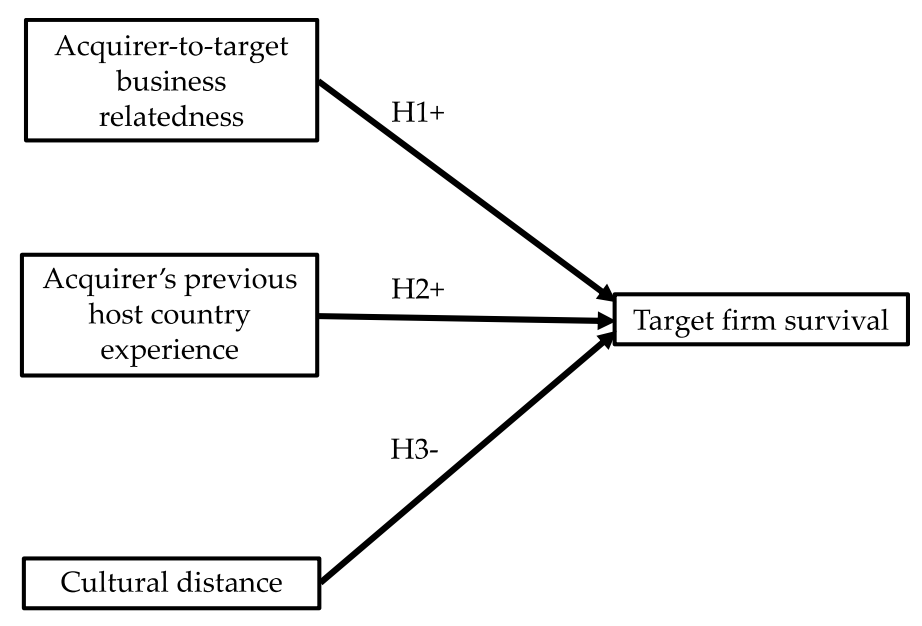

Figure 1. Conceptual model and hypotheses.

\section{Methodology}

\subsection{Research Context}

In Europe, the growing harmonization of regulation and the progressive creation of a homogeneous market have substantially reduced the completion time and streamlined cross-border acquisitions [84]. In this scenario, Italy has been steadily suffering from a weak position in terms of foreign direct investments (FDI) attraction if compared to other European countries [85].

The lower competitiveness of Italy for FDI attraction results both from the typical specialization model of the Italian industrial system, characterized by the deeply rooted dominance of traditional manufacturing sectors and of family ownership, and from institutional aspects such as bureaucratic burdens, judicial system slowness, along with the absence of a well-developed capital market favoring ownership transfers. Indeed, although traditionally considered as an advanced economy within the European Union, the Italian context is characterized by multiple peculiarities and weaknesses compared to US and other large European countries. Information asymmetries, the limited development of capital markets, and opportunistic behaviors in the use of firms' free cash flows by managers and large controlling shareholders against minority shareholders represent just a few examples of the various inefficiencies of the Italian business and institutional context [86-88]. Furthermore, the Italian industrial system is characterized by several distinctive features compared to other countries both 
within and outside Europe, especially in terms of size, ownership, and international orientation of firms. Indeed, small- and medium-sized enterprises (SMEs) and family businesses constitute the dominant part of the country's economy, and large firms are relatively few compared to SMEs. In terms of international orientation, while Italian firms have a high propensity towards export as a topical mode to join competition in the global arena [89], with the European Union countries absorbing more than $50 \%$ of Italian export goods, the amount of inbound FDIs is relatively low in comparison with other developed countries, thus suggesting that the attractiveness of Italian goods and of the Italian context actually follow different paths.

In most recent years, thanks to financial and labor market reforms, the competitiveness of Italy has increased: According to the United Nations Conference on Trade and Development (UNCTAD) [90], during the 2013-2015 three-year period, Italy was able to attract approximately USD 67 billion (+50\% if compared to the previous three-year period). Especially during the last years, Italian firms have been increasingly regarded as attractive targets of acquisitions by foreign multinationals interested in acquiring popular brands of 'Made in Italy', including traditional manufacturing industries such as food, mechanical/automation, furnishing, and clothing [89]. If, on the one hand, this phenomenon highlights an increased competitiveness of the Italian business context, on the other, it raises concerns about the effects that such deals may generate on the future of acquired firms, i.e., on the survival of target firms after being taken over. Italy therefore represents a unique and interesting research setting for the purposes of our research, since the inefficiencies of the institutional environment combined with the strategic attractiveness of 'Made in Italy' firms for foreign investors may substantially affect the sustainability of cross-border acquisitions in this country.

\subsection{Sample and Data Collection}

The hypotheses have been tested on a sample of 396 cross-border acquisitions in Italy in the period 2005-2015. The year 2005 indeed represented a severe year for the Italian business context, with more than 90,000 firms registering failure, while 2015 is considered as a turning point in the direction of increased survival rate of Italian firms [91]. As a result, the 11-year timeframe of our study can be considered as adequate to capture variation in the Italian macroenvironment. Two additional reasons justify the use of 2015 as a final year of the timeframe under investigation. First, literature has suggested that the completion of the entire acquisition process may require up to three years [92], thus indicating that we should account for an extended period of time beyond the deal completion date to better appreciate the likelihood of firms' survival versus dissolution. Second, firm dissolution can be driven by either liquidation/bankruptcy or divestment decisions and, in both cases, its full accomplishment requires a relatively long period. Specifically, if considering liquidation/bankruptcy, the average time for resolving insolvency in Italy is 1.8 years [93]. Similarly, in case firms' dissolution is driven by divestment, it should be noted that divestment actually involves the development of dynamic capabilities for the reconfiguration of a firm's resource portfolio [94] and represents a decision that managers are likely to hold in reserve and that may be hence better understood within longer timeframes [95].

The source of the sampled observations is the database Zephyr (Bureau Van Dijk) and the selection process has been based on the following criteria: (i) Acquisitions completed between 1 January 2005 and 12 December 2015-only completed acquisitions were included in the sample, thereby excluding cases of announcements, rumors, or withdrawals; (ii) acquisitions made by foreign investors in Italy as target country; (iii) "pure acquisitions", i.e., acquisitions in which the acquirer does not own any previous stake in the acquired firm, thereby excluding acquisitions for increasing already existing ownership stakes; (iv) acquisitions involving entire companies, thus excluding branches and individual assets. These criteria led to an initial dataset of 830 acquisitions. Due to the unavailability of data related to the status of target firms, this representing our research focus, the final sample consists of 396 observations.

The distribution of deals by year in both absolute numbers and in percentage is provided in Figure 2. 


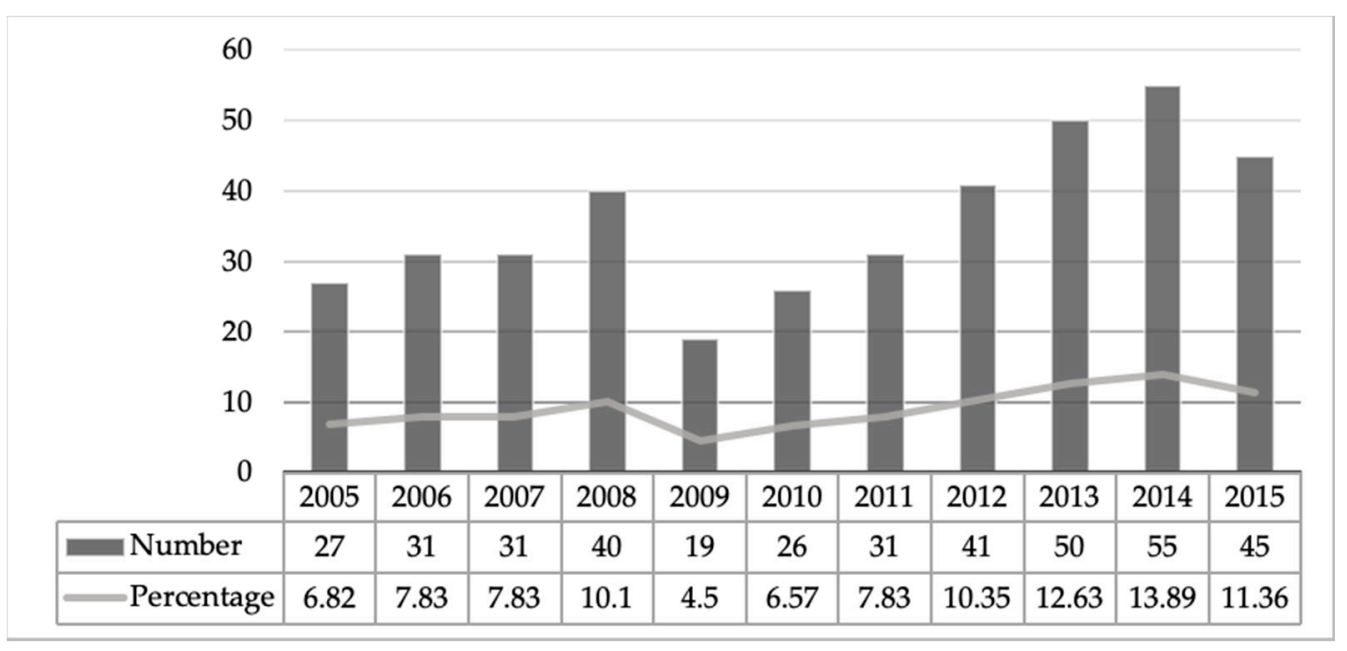

Figure 2. Distribution of cross-border acquisitions in Italy by year.

With a rather steady trend in the period 2005-2008, a significant reduction of acquisition activity in Italy occurred during 2009, the year in which the global economic crisis exploded. Starting from 2010, however, the volume of cross-border acquisitions in Italy started to grow again, until in 2013-2015 it even exceeded the pre-crisis volume.

To analyze the distribution of both acquiring and acquired firms by industry, sectors have been clustered on the basis of the North American Industrial Classification System (NAICS) codes of acquirers (Table 1) and target companies (Table 2) at two-digit level.

Table 1. Distribution of acquisitions by acquiring firm's industry.

\begin{tabular}{|c|c|c|}
\hline Acquiring Firm Industry & Number & Percentage \\
\hline Mining and extraction, utilities, and construction & 28 & $7.07 \%$ \\
\hline $\begin{array}{l}\text { Manufacturing (The Manufacturing sector includes: NAICS } 31 \text { (25 firms), } \\
\text { NAICS } 32 \text { (43 firms), NAICS } 33 \text { (124 firms)) }\end{array}$ & 192 & $48.48 \%$ \\
\hline Trade and transportation & 46 & $11.62 \%$ \\
\hline $\begin{array}{l}\text { Services (The Services sector includes: NAICS } 51 \text { (18 firms), NAICS } 52 \\
\text { ( } 23 \text { firms), NAICS } 53 \text { (6 firms), NAICS } 54 \text { ( } 50 \text { firms), NAICS } 55 \text { ( } 5 \text { firms), } \\
\text { NAICS } 56 \text { (10 firms)) }\end{array}$ & 112 & $28.28 \%$ \\
\hline $\begin{array}{l}\text { Other sectors (Other sectors include: NAICS } 1 \text { ( } 1 \text { firm), NAICS } 6 \text { (7 firms), } \\
\text { NAICS } 7 \text { ( } 7 \text { firms), NAICS } 8 \text { ( } 1 \text { firm), NAICS } 9 \text { ( } 2 \text { firms) })\end{array}$ & 18 & $4.55 \%$ \\
\hline Total & 396 & $100.00 \%$ \\
\hline
\end{tabular}

Table 2. Distribution of acquisitions by acquired firm's industry.

\begin{tabular}{|c|c|c|}
\hline Target Firm Industry & Number & Percentage \\
\hline Mining and extraction, utilities, and construction & 28 & $7.07 \%$ \\
\hline $\begin{array}{l}\text { Manufacturing (The Manufacturing sector includes: NAICS } 31 \text { (31 firms), } \\
\text { NAICS } 32 \text { (42 firms), NAICS } 33 \text { (110 firms)) }\end{array}$ & 194 & $48.99 \%$ \\
\hline Trade and transportation & 50 & $12.63 \%$ \\
\hline $\begin{array}{l}\text { Services (The Services sector includes: NAICS } 51 \text { (17 firms), NAICS } 52 \\
\text { (13 firms), NAICS } 53 \text { ( } 6 \text { firms), NAICS } 54 \text { ( } 58 \text { firms), NAICS } 55 \text { (1 firm), } \\
\text { NAICS } 56 \text { (12 firms)) }\end{array}$ & 107 & $27.02 \%$ \\
\hline $\begin{array}{l}\text { Other sectors (Other sectors include: NAICS } 6 \text { ( } 5 \text { firms), NAICS } 7 \text { (7 firms), } \\
\text { NAICS } 8 \text { ( } 3 \text { firms), NAICS } 9 \text { ( } 2 \text { firms)) }\end{array}$ & 17 & $4.29 \%$ \\
\hline Total & 396 & $100.00 \%$ \\
\hline
\end{tabular}


Most foreign investors are active in the manufacturing industry (192 firms), of which 25 operate in the manufacturing of food, beverage, and textile, 43 operate in paper and wood manufacturing and in chemicals manufacturing, while the majority (124 firms) are involved in machinery, computer, and electrical products manufacturing, as well as in furniture manufacturing. Moving to the examination of target firms, Table 2 displays a distribution that looks very similar to that of acquiring firms: The majority of acquisitions involves firms in the manufacturing industry (194 deals, $48.99 \%$ of observation), immediately followed by the services sector with 107 target firms.

When considering the distribution by acquiring firms' home country, Table 3 shows a clear predominance of acquirers from European Union (EU) with 312 investors, followed by Asia with 29 acquiring firms, and by other European countries (not members of EU) with 27.

Table 3. Distribution of acquirers by geographic area.

\begin{tabular}{ccc}
\hline Geographic Area & Number & Percentage \\
\hline European Union (EU27) & 312 & $78.79 \%$ \\
Asia & 29 & $7.32 \%$ \\
Other European countries & 27 & $6.82 \%$ \\
NAFTA & 19 & $4.80 \%$ \\
Middle East & 4 & $1.01 \%$ \\
Oceania & 2 & $0.51 \%$ \\
Centre and South America & 2 & $0.51 \%$ \\
Africa & 1 & $0.25 \%$ \\
Total & 396 & $\mathbf{1 0 0 . 0 0 \%}$ \\
\hline
\end{tabular}

In general terms, only 57 acquisitions (14.39\% of the sample) come from non-European countries. It is also worth noting that $90.91 \%$ of acquisitions observed are made by acquirers coming from developed countries, while only 36 acquisitions $(9.09 \%)$ are associated with acquirers from emerging economies, as defined by Hoskisson et al. [96].

\subsection{Variables and Measures}

The dependent variable is the target firm survival, operationalized as a dichotomous variable that takes value 1 when the acquired firm is still active (with either the same firm name or a new one) at the moment of data collection and 0 in case the subsidiary is dissolved or in liquidation/bankruptcy [35]. Case 1 includes 296 survived firms (74.75\% of the observations), of which 239 still have the same name while 57 changed their name; case 0 includes 100 firms ( $25.25 \%$ of observations), of which 75 are already dissolved while 25 are in liquidation (Table 4).

Table 4. Distribution of target firms by status.

\begin{tabular}{ccc}
\hline Status Target Firm & Number & Percentage \\
\hline Active with same name & 239 & $60.35 \%$ \\
Active with different name & 57 & $14.39 \%$ \\
Dissolved & 75 & $18.94 \%$ \\
In liquidation & 25 & $6.31 \%$ \\
Total & 396 & $\mathbf{1 0 0 . 0 0 \%}$ \\
\hline
\end{tabular}

The variable of acquirer-to-target business relatedness has been built based on the match between the NAICS codes of acquirer and target core businesses at two-digit level. This dichotomous variable takes value 1 when acquirer and target have the same two-digit NAICS codes, i.e., they operate in the same business, and value 0 when there is no match between the two-digit NAICS codes. The 0 -case, therefore, identifies those acquisitions in which a diversification strategy is implemented and, hence, those firms for which entering Italy is also associated with venturing into a different business. In our 
sample, 258 acquisitions are characterized by business-level similarity between acquirer and target, while 138 acquisitions involve business diversification.

The variable of acquirer's host country experience is a dichotomous variable taking value 1 if the acquiring firm already owns subsidiaries in Italy at the moment in which the focal acquisition is executed, and value 0 , as opposite, when the focal acquisition represents the first investment in Italy [4]. In our sample, 302 deals have been executed by experienced firms, while 94 acquisitions have been carried out by first-time investors in Italy.

The variable of cultural distance has been measured following Chakrabarti et al. [73], i.e., as the distance between Hofstede's [97,98] orthogonal dimensions of power distance, individualism, masculinity, uncertainty avoidance, long-term orientation, and indulgence.

In addition to our main variables, the analysis includes several control variables at firm-, deal-, and industry-level. Control variables at firm-level include the pre-deal diversification status of both acquirer and target, and acquirer size.

Diversification has been found to provide firms with a repository of geographically fungible resources and capabilities that can be leveraged when implementing an international expansion, for instance through a cross-border acquisition [99-101]. We hence include in our model two control variables capturing the diversification status of both acquiring and target firm before the focal acquisition. Following an established practice in the literature [102,103], the variables related to the pre-deal diversification status were operationalized as follows: The variable capturing the acquirer pre-deal diversification status is a dichotomous measure based on the number of NAICS codes in which the acquiring firm is active and takes value 1 if the acquirer is a multi-business firm, i.e., it operates in two or more businesses, and value 0 if the acquirer operates in only one business. The variable capturing the target pre-deal diversification status has been measured consistently.

Following prior literature, we also control for acquirer size. Size indeed represents an important condition that affects the level of financial and managerial resources that can be committed to the execution of the entire acquisition process [54], with potential implications in terms of extent to which dynamic capabilities can be displayed. The variable capturing the size of the acquiring firm has been measured as the log-transformed acquiring firm's total assets before the focal acquisition [104]. The model also includes two sets of control variables at deal- and industry-level. Specifically, to account for time effects deriving from the year in which the deal was completed, 10 dichotomous variables were included with the year 2015 representing the baseline year. Finally, as long as industry effects are concerned, we included four dichotomous variables identifying the four macro-industries shown in Table 2, with "other sectors" representing the baseline industry.

\section{Results}

Table 5 displays the descriptive statistics and the correlation matrix. The low correlation coefficients suggest that multicollinearity did not bias our results.

Table 6 shows the results of the econometric analysis: In line with the nature of our dependent variable as a dichotomous variable, a logistic regression was performed. Model 1 in Table 6 displays the results for a model including only the control variables, while in Model 2 the three independent variables are added.

Hypothesis 1 predicted a positive relationship between parent-subsidiary business relatedness and the survival of the acquired subsidiary. This hypothesis receives marginal support (Model 2, $\beta=0.50, p<0.10$ ): the findings indicate a positive coefficient, which is consistent with our prediction that at greater business similarity between acquirer and target, the likelihood of survival increases.

The analysis provides strong support for our Hypothesis 2, which posited that the acquirer's host country experience has a positive effect on the target firm survival (Model 2, $\beta=0,92, p<0.01$ ): The likelihood of survival increases significantly when the acquiring firm already operates in Italy through previously established subsidiaries. Specifically, 240 target firms that survived (60\% of our total sample) were acquired by foreign companies having previous equity-based experience in Italy. 
Table 5. Descriptive statistics and correlation matrix.

\begin{tabular}{|c|c|c|c|c|c|c|c|c|c|}
\hline & Variables & Mean & S.D. & (1) & (2) & (3) & (4) & (5) & (6) \\
\hline (1) & Target firm survival & 0.74 & 0.43 & 1.00 & & & & & \\
\hline (2) & $\begin{array}{c}\text { Acquirer-to-target } \\
\text { business relatedness }\end{array}$ & 0.65 & 0.47 & 0.06 & 1.00 & & & & \\
\hline (3) & $\begin{array}{l}\text { Acquirer's host } \\
\text { country experience }\end{array}$ & 0.76 & 0.42 & 0.19 * & -0.03 & 1.00 & & & \\
\hline (4) & Cultural distance & 1.43 & 0.98 & 0.00 & 0.00 & 0.02 & 1.00 & & \\
\hline (5) & $\begin{array}{c}\text { Acquirer pre-deal } \\
\text { diversification status }\end{array}$ & 1.17 & 0.93 & 0.08 & 0.03 & 0.02 & -0.09 & 1.00 & \\
\hline (6) & $\begin{array}{c}\text { Target pre-deal } \\
\text { diversification status }\end{array}$ & 0.80 & 0.93 & 0.07 & 0.06 & -0.11 & $-0.02 *$ & $0.15 *$ & 1.00 \\
\hline (7) & Acquirer size & 19.04 & 3.26 & $-0.11^{*}$ & 0.09 & 0.10 & $-0.07 *$ & 0.14 * & -0.05 \\
\hline
\end{tabular}

Table 6. Logistic regression—Dependent variable: Target firm survival.

\begin{tabular}{ccc}
\hline Variables & Model 1 & Model 2 \\
\hline Independent variables & & \\
Acquirer-to-target business relatedness & & $0.50^{*}(0.27)$ \\
Acquirer's host country experience & & $0.92^{* * *}(0.28)$ \\
Cultural distance & $0.02(0.13)$ \\
Control variables & & \\
2005 & $-1.76^{* *}(0.74)$ & $-1.45^{*}(0.77)$ \\
2006 & $-1.50^{* *}(0.74)$ & $-1.31^{*}(0.76)$ \\
2007 & $-1.81^{* *}(0.73)$ & $-1.72^{* *}(0.74)$ \\
2008 & $-2.19^{* * *}(0.70)$ & $-1.86^{* *}(0.72)$ \\
2009 & $-2.50^{* * *}(-0.78)$ & $-2.42^{* * *}(0.79)$ \\
2010 & $-0.77(0.82)$ & $-0.73(0.84)$ \\
2011 & $-1.96^{* * *}(0.72)$ & $-1.92^{* *}(0.74)$ \\
2012 & $-1.07(0.73)$ & $-1.02(0.74)$ \\
2013 & $-0.91(0.73)$ & $-0.84(0.75)$ \\
2014 & $-0.99(0.70)$ & $-0.92(0.72)$ \\
Manufacturing & $-0.46(0.69)$ & $-0.68(0.73)$ \\
Mining and extraction, utilities, construction & $0.38(0.59)$ & $0.06(0.63)$ \\
Trade and transportation & $0.10(0.66)$ & $0.10(0.70)$ \\
Services & $0.39(0.61)$ & $0.18(0.64)$ \\
Pseudo R2 & $0.23^{*}(0.13)$ & $0.26^{*}(0.14)$ \\
Acquirer pre-deal diversification status & $0.05(0.14)$ & $0.08(0.14)$ \\
Target pre-deal diversification status & $-0.05(0.04)$ & $-0.08^{*}(0.04)$ \\
Acquirer size & $3.05^{* * *}(1.10)$ & $2.66^{* *}(1.17)$ \\
Intercept & 396 & 396 \\
Number of observations & $40.76^{* * *}$ & $53.70 * * *$ \\
\hline Not & 0.09 & 0.12 \\
\hline
\end{tabular}

Notes: Standard errors are in parentheses. Significance levels: ${ }^{*} p<0.1,{ }^{* *} p<0.5,{ }^{* * *} p<0.01$.

Hypothesis 3 predicted a negative effect of cultural distance on the survival of acquired firms. This hypothesis does not receive any support. As an additional analysis, an alternative variable has been used as a proxy of geographic distance. Geographic distance is indeed conceptually close to cultural distance since they are both a source of internal uncertainty, e.g., [82,105]. We therefore built a dichotomous measure taking value 1 for non-European acquirers and value 0 for European acquirers. However, no support was found for a negative relationship between distance and survival likelihood. Additionally, the distinction between acquiring firms from developed countries versus emerging countries [96] is not associated with any significant difference in terms of survival of the acquired firms. 
While research on cultural distance has yielded mixed findings, pointing to both positive and negative effects, our results are actually in line with a number of studies that found no effects, e.g., [5,26,106,107].

As long as control variables are concerned, the survival of acquired firms is positively associated with the acquirer pre-deal diversification status (Model 2, $\beta=0.26, p<0.10$ ), thus indicating that diversified acquirers have a bundle of fungible resources and competencies that can be leveraged in the parent-subsidiary relationship. Our findings also suggest that the survival of target firms is negatively associated with acquirer size (Model $2, \beta=-0.08, p<0.10$ ): While organizational size has been recognized as a proxy of the available resources, both financial and managerial, that the acquiring company can invest in the management of the acquisition [54], this result may indicate that larger firms suffer from more bureaucratic decision-making [108] and greater inertia [109] that hampers the effectiveness of knowledge transfer.

While at industry level no statistically significant effect emerges, it is worth noting that, in line with expectations, the likelihood of survival depreciates over time: In particular, if compared to target firms acquired in 2015, the probability of survival is significantly lower for firms acquired in the first years of our sample.

\section{Discussion}

Overall, the analysis focuses on three main antecedents of the likelihood of acquired firms' survival after cross-border acquisitions: Business relatedness between acquirer and target, acquirer host country experience, and cultural distance. Our results on the association between business relatedness and target firms' survival confirm that a greater similarity at business level between acquirer and target provides benefits in terms of reduced uncertainty [52] and development of resources and competencies that may be transferred to the acquired firm $[4,55]$, which, in turn, may increase the potential synergies and the extent to which the acquisition contributes to enhancing the target firm's sustainable competitive advantage. This evidence is also in line with the process perspective on acquisitions [31]. Specifically, it reveals that similarity at business level may not only result in a more effective evaluation of strategic fit in the preliminary stage of target valuation but may also enable acquiring firms to create an environment that is conducive to social integration and knowledge transfer.

Empirical results confirm that previous host country experience positively affects the survival of target firms. From an international business perspective, this result is fully consistent with the argument that costs associated with liability of foreignness are not static and, rather, decline as the firm gains knowledge of the target market [110]. Acquiring firms benefiting from previous experience in Italy have gained knowledge of the specificities of the cultural, institutional, and competitive environment, which may lead to an increased familiarity with and legitimation in the local context [22]. From a knowledge-based perspective, experienced acquirers indeed have developed specific resources, capabilities, and knowledge bases that can be effectively transferred to the locally acquired subsidiary [10], which in the absence of any previous host country experience would be extremely difficult $[35,68]$.Therefore, this finding suggests that the accumulation of experience in the target context increases the likelihood of survival of foreign acquired subsidiaries, because host country experience acts as a crucial factor determining the extent to which strategic resources and knowledge can be transferred from the parent to the subsidiary $[3,10]$.

Since we measured our variable of host country experience with an equity-based operationalization, i.e., we considered whether the acquirer owns subsidiaries in Italy before the focal acquisition, our finding is in line with studies suggesting that equity-based experience implies greater commitment of resources and is associated with a greater market knowledge [70].

Our findings do not provide support to our prediction that cultural distance should play a negative effect on target firms' survival because of the greater difficulty of transferring knowledge at increasing distance. The lack of a statistically significant effect of cultural distance is, however, not totally surprising, especially when considering the substantially mixed findings obtained over the years [73]. Indeed, because cultural distance does not necessarily imply cultural incompatibility [111,112], some studies have hypothesized that distance could also prove beneficial as it may produce competitive advantages, 
in terms of access to distinctive competencies and incentives to innovation, fostering learning and encouraging acquirers towards a more cautious target valuation and selection [73]. The non-significant effect of cultural distance on the survival of foreign acquired subsidiaries is also in line with a number of studies that did not find any support for either a positive or negative effect, e.g., [5,26].

Furthermore, while we built on an established methodological route for the operationalization of cultural distance $[21,73]$, this measurement approach does not consider potential variances in cultural dimensions over time [113]. The lack of significance of cultural distance may hence testify that the increased interconnections and communication possibilities brought about by globalization are actually more and more determining a convergence of cultural systems [113]. This result should be interpreted in the light of extant literature suggesting that distance is actually a multifaceted concept [56]: While cultural distance has been extensively recognized as a critical factor affecting the degree to which firm-specific advantages can be transferred to host locations, the analysis of the additional dimensions of distance may further our understanding of the survival of foreign affiliates.

\section{Implications and Conclusions}

In the vast body of literature on acquisitions, the deeply rooted direction of most studies to focus on post-acquisition value creation at acquiring firm level has raised the need to investigate the implications at subsidiary level [10]. This paper offers a contribution to the research stream on subsidiary survival in the context of cross-border acquisitions from multiple respects.

From a theoretical point of view, this study contributes to the promising research area on the linkage between cross-border acquisitions and the sustainability of firms' competitive advantages, e.g., [18-20], by examining the effects on Italian target firms acquired by foreign investors. Overall, our results offer some interesting implications for both managers and policymakers and contribute to shed light on the sustainability of international competitiveness of Italian firms in the global competitive environment.

In Italy, the international competitiveness of firms is currently a widely debated subject in terms of whether foreign investments enhance or are detrimental to firms' competitiveness. Recent changes in the world economy related to the role of emerging economies have raised new challenges for Italian firms, which are experiencing increasing competitive pressures especially in the traditional manufacturing industries in which they have always had a strong competitive position, i.e., the so called 'Made in Italy' industries including food, mechanical/automation, furnishing, and clothing. Our study indicates that a response to this highly debated role of foreign investments on the competitiveness of foreign subsidiaries is contingent upon the characteristics of foreign investors in terms of business relatedness and experience. Indeed, the future of acquired firms appears to be more a function of the familiarity at both country and business level rather than of distance: The investor's familiarity with both the institutional and the business contexts plays a key role in facilitating the knowledge transfer process and, hence, in influencing the sustainable development of acquired firms. These findings also provide insights for practice and, in particular, for managers of acquiring firms. When executing acquisitions, especially in the context of cross-border acquisitions, it is crucial for firms to design the integration approach to be implemented [31]. In this sense, our study suggests that in order to plan the execution of the integration process, acquiring firms' managers should consider their familiarity at both business and country-level.

This paper is not without limitations, primarily due to the limited generalizability of results. Our sample included Italian subsidiaries acquired by foreign investors over an 11-year period: Considering the important role played by the 'Made in Italy' concept, the survival of Italian firms may actually incorporate a host of parent firms' strategic considerations related to the value of the subsidiary within their overall strategic posture and resource portfolio at corporate level. From a methodological point of view, we also acknowledge the need to more accurately operationalize the survival of acquired firms, for instance by using hazard rate models and by integrating the temporal dynamic, i.e., the temporal evolution of the acquired firm status. 
In spite of these limitations, we offer a contribution from multiple respects to the emerging literature on the sustainability of cross-border acquisitions in terms of survival of foreign subsidiaries and provide some interesting avenues for future research. For instance, some scholars have identified the important role played by expatriates in transferring knowledge to the foreign subsidiaries [8]. Since expatriates act as facilitators of transfer, it would be interesting to explore whether the extent to which parent firms rely on expatriates may be associated with a greater likelihood of survival of target firms.

While previous host country experience represents an important source of knowledge of the specificities of the target context in cross-border acquisitions, our measure of host country experience is purely equity-based, i.e., we consider whether acquiring firms already have subsidiaries in Italy before the focal acquisition. Equity-based entry modes in foreign countries are acknowledged to provide more in-depth experience of a target context since they involve greater commitment and hence provide greater market knowledge and embeddedness [70], but future research may extend our analysis and investigate whether non-equity-based experience, through exports or licensing for instance, may carry different implications on the survival of foreign acquired affiliates.

Finally, since our results on cultural distance do not provide empirical support to our prediction that cultural differences at national level may play a role on the survival of acquired subsidiaries, future research might explore the effects of other types of distance, including for instance the institutional, normative, regulatory, and economic distances among others. Unbundling the multifaceted construct of distance into its diverse facets may indeed provide additional insights into the role that differences of various nature may play on the survival of acquired firms.

Author Contributions: Conceptualization, I.G. and D.C.; methodology and data analysis, D.C.; writing—original draft preparation, I.G.; writing—review and editing, I.G., D.C., and F.C.; supervision, I.G. and F.C. All authors have read and agreed to the published version of the manuscript.

Funding: This research received no external funding.

Conflicts of Interest: The authors declare no conflict of interest.

\section{References}

1. Shaver, J.M.; Mitchell, W.; Yeung, B. The Effect of Own-Firm and Other-Firm Experience on Foreign Direct Investment Survival in the United States. Strateg. Manag. J. 1997, 18, 811-824. [CrossRef]

2. Birkinshaw, J.; Hood, N. Multinational subsidiary evolution: Capability and charter change in foreign-owned subsidiary companies. Acad. Manag. Rev. 1998, 23, 773-795. [CrossRef]

3. Delios, A.; Beamish, P.W. Survival and profitability: The roles of experience and intangible assets in foreign subsidiary performance. Acad. Manag. J. 2001, 44, 1028-1038.

4. $\mathrm{Li}$, J. Foreign entry and survival: The effects of strategic choices on performance in international markets. Strateg. Manag. J. 1995, 16, 333-351. [CrossRef]

5. Barkema, H.G.; Bell, J.; Pennings, J.M. Foreign Entry, Cultural Barriers, and Learning. Strateg. Manag. J. 1996, 17, 151-166. [CrossRef]

6. Barkema, H.G.; Shenkar, O.; Vermeulen, F.; Bell, J.H. Working abroad, working with others: How firms learn to operate international joint ventures. Acad. Manag. J. 1997, 40, 426-442.

7. Baek, H.Y.; Min, S.; Ryu, S. The Effects of Agency Problems on the Stability of the International Joint Venture. Multinatl. Bus. Rev. 2006, 14, 53-70. [CrossRef]

8. Lu, J.W.; Hebert, L. Equity control and the survival of international joint ventures: A contingency approach. J. Bus. Res. 2005, 58, 736-745. [CrossRef]

9. Mohr, A.; Wang, C.; Fastoso, F. The contingent effect of state participation on the dissolution of international joint ventures: A resource dependence approach. J. Int. Bus. Stud. 2016, 47, 408-426. [CrossRef]

10. Uhlenbruck, K. Developing acquired foreign subsidiaries: The experience of MNEs in transition economies. J. Int. Bus. Stud. 2004, 35, 109-123. [CrossRef]

11. Shimizu, K.; Hitt, M.A. What Constrains or Facilitates Divestitures of Formerly Acquired Firms? The Effects of Organizational Inertia. J. Manag. 2005, 31, 50-72. [CrossRef] 
12. Kusewitt, J.B. An Exploratory Study of Strategic Acquisition Factors Relating to Performance. Strateg. Manag. J. 1985, 6, 151-169. [CrossRef]

13. Zollo, M.; Singh, H. Deliberate learning in corporate acquisitions: Post-acquisition strategies and integration capability in US bank mergers. Strateg. Manag. J. 2004, 25, 1233-1256. [CrossRef]

14. Barkema, H.G.; Schijven, M. Toward unlocking the full potential of acquisitions: The role of organizational restructuring. Acad. Manag. J. 2008, 51, 696-722.

15. Chao, Y.C. Organizational learning and acquirer performance: How do serial acquirers learn from acquisition experience? Asia Pac. Manag. Rev. 2018, 23, 161-168. [CrossRef]

16. Finkelstein, S.; Haleblian, J. Understanding Acquisition Performance: The Role of Transfer Effects. Organ. Sci. 2002, 13, 36-47. [CrossRef]

17. Huang, Z.; Zhu, H.S.; Brass, D.J. Cross-Border Acquisitions and the Asymmetric Effect of Power Distance Value Difference on Long-Term Post-Acquisition Performance. Strateg. Manag. J. 2017, 38, 972-991. [CrossRef]

18. Hečková, J.; Štefko, R.; Frankovský, M.; Birknerová, Z.; Chapčáková, A.; Zbihlejová, L. Cross-Border Mergers and Acquisitions as a Challenge for Sustainable Business. Sustainability 2019, 11, 3130. [CrossRef]

19. González-Torres, T.; Rodríguez-Sánchez, J.L.; Pelechano-Barahona, E.; García-Muiña, F.E. A systematic review of research on sustainability in mergers and acquisitions. Sustainability 2020, 12, 513. [CrossRef]

20. Choi, J.; Shin, N.; Lee, H.S. Exploring the Dynamics between M\&A Activities and Industry-Level Performance. Sustainability 2020, 12, 4399.

21. Kogut, B.; Singh, H. The effect of national culture on the choice of entry mode. J. Int. Bus. Stud. 1988, 19, 411-432. [CrossRef]

22. Zaheer, S. Overcoming the liability of foreignness. Acad. Manag. J. 1995, 38, 341-363.

23. Morck, R.; Yeung, B. Why investors value multinationality. J. Bus. 1991, 64, 165-187. [CrossRef]

24. Caves, R.E. Economic Analysis and the Multinational Corporation, 2nd ed.; Cambridge University Press: Cambridge, UK, 1996.

25. Reus, T.H. A Knowledge-Based View of Mergers and Acquisitions Revisited: Absorptive Capacity and Combinative Capability. In Advances in Mergers and Acquisitions; Finkelstein, S., Cooper, C.L., Eds.; Emerald Group Publishing Limited: Bingley, UK, 2012; Volume 11, pp. 69-88.

26. Ahammad, M.F.; Tarba, S.Y.; Liu, Y.; Glaister, K.W. Knowledge transfer and cross-border acquisition performance: The impact of cultural distance and employee retention. Int. Bus. Rev. 2016, 25, 66-75. [CrossRef]

27. Wang, X.; Xi, Y.; Xie, J.; Zhao, Y. Organizational unlearning and knowledge transfer in cross-border M\&A: The roles of routine and knowledge compatibility. J. Knowl. Manag. 2017, 22. [CrossRef]

28. Lyles, M.A.; Salk, J.E. Knowledge acquisition from foreign parents in international joint ventures: An empirical examination in the Hungarian context. J. Int. Bus. Stud. 1996, 27, 877-903. [CrossRef]

29. Grant, R.M. Toward a knowledge-based theory of the firm. Strateg. Manag. J. 1996, 17, 109-122. [CrossRef]

30. Jiménez-Barrionuevo, M.; Molina, L.M.; García-Morales, V.J. Combined influence of absorptive capacity and corporate entrepreneurship on performance. Sustainability 2019, 11, 3034. [CrossRef]

31. Haspeslagh, P.C.; Jemison, D.B. Managing Acquisitions: Creating Value through Corporate Renewal; Free Press: New York, NY, USA, 1991.

32. Teece, D.J.; Pisano, G.; Shcuen, A. Dynamic Capabilities and Strategic Management. Strateg. Manag. J. 1997, 18, 509-533. [CrossRef]

33. Zollo, M.; Winter, S.G. Deliberate Learning and the Evolution of Dynamic Capabilities. Organ. Sci. 2002, 13, 339-351. [CrossRef]

34. Lane, P.J.; Lubatkin, M. Relative absorptive capacity and interorganizational learning. Strateg. Manag. J. 1998, 19, 461-477. [CrossRef]

35. Hébert, L.; Very, P.; Beamish, P.W. Expatriation as a bridge over troubled water: A knowledge-based perspective applied to cross-border acquisitions. Organ. Stud. 2005, 26, 1455-1476. [CrossRef]

36. Sohn, J.H.D. Social knowledge as a control system: A proposition and evidence from the Japanese FDI behavior. J. Int. Bus. Stud. 1994, 25, 295-324. [CrossRef]

37. Zaheer, S.; Mosakowski, E. The dynamics of the liability of foreignness: A global study of survival in financial services. Strateg. Manag. J. 1997, 18, 439-463. [CrossRef]

38. Reus, T.H.; Lamont, B.T. The double-edged sword of cultural distance in international acquisitions. J. Int. Bus. Stud. 2009, 40, 1298-1316. [CrossRef] 
39. Barkema, H.; Vermeulen, F. International expansion through start-up or acquisition: A learning perspective. Acad. Manag. J. 1998, 41, 7-26.

40. Morosini, P.; Shane, S.; Singh, H. National cultural distance and cross-border acquisition performance. J. Int. Bus. Stud. 1998, 29, 137-158. [CrossRef]

41. Eisenhardt, K.M.; Martin, J.A. Dynamic capabilities: What are they? Strateg. Manag. J. 2000, 21, 1105-1121. [CrossRef]

42. Kogut, B.; Zander, U. Knowledge of the Firm, Combinative Capabilities, and the Replication of Technology. Organ. Sci. 1992, 3, 383-397. [CrossRef]

43. Cohen, W.M.; Levinthal, D.A. Absorptive Capacity: A New Perspective on Learning and Innovation. Adm. Sci. Q. 1990, 35, 128-153. [CrossRef]

44. Zahra, S.A.; George, G. Absorptive capacity: A review, reconceptualization, and extension. Acad. Manag. Rev. 2002, 27, 185-203. [CrossRef]

45. Lane, P.J.; Salk, J.E.; Lyles, M.A. Absorptive capacity, learning, and performance in international joint ventures. Strateg. Manag. J. 2001, 22, 1139-1161. [CrossRef]

46. Hennart, J.F.; Kim, D.J.; Zeng, M. The impact of joint venture status on the longevity of Japanese stakes in US manufacturing affiliates. Organ. Sci. 1998, 9, 382-395. [CrossRef]

47. Tang, J.; Rowe, W.G. The liability of closeness: Business relatedness and foreign subsidiary performance. J. World Bus. 2012, 4, 288-296. [CrossRef]

48. Seth, A. Value creation in acquisitions: A re-examination of performance issues. Strateg. Manag. J. 1990, 11, 99-115. [CrossRef]

49. Datta, D.K. Organizational Fit and Acquisition Performance: Effects of Post-Acquisition Integration. Strateg. Manag. J. 1991, 12, 281-297. [CrossRef]

50. Park, C. The effects of prior performance on the choice between related and unrelated acquisitions: Implications for the performance consequences of diversification strategy. J. Manag. Stud. 2002, 39, 1003-1019. [CrossRef]

51. Jemison, D.B.; Sitkin, S.B. Corporate acquisitions: A process perspective. Acad. Manag. Rev. 1986, 11, 145-163. [CrossRef]

52. Caves, R.E. Multinational Enterprise and Economic Analysis; Cambridge University Press: Cambridge, UK, 1982.

53. Galavotti, I.; Depperu, D.; Cerrato, D. Acquirer-to-target relatedness and target country unfamiliarity in acquisitions. Manag. Decis. 2017, 55, 892-914. [CrossRef]

54. Laamanen, T.; Keil, T. Performance of Serial Acquirers: Toward an Acquisition Program Perspective. Strateg. Manag. J. 2008, 29, 663-672. [CrossRef]

55. Bane, W.T.; Neubauer, F.F. Diversification and the failure of new foreign activities. Strateg. Manag. J. 1981, 2, 219-333. [CrossRef]

56. Pehrsson, A. Business relatedness in international diversification. Eur. Bus. Rev. 2019, 31, 197-217. [CrossRef]

57. Glaister, K.W.; Buckley, P.J. Task-related and partner-related selection criteria in UK international joint ventures. Br. J. Manag. 1997, 8, 199-222. [CrossRef]

58. Park, B.I.; Giroud, A.; Glaister, K.W. Acquisition of managerial knowledge from foreign parents: Evidence from Korean joint ventures. Asia Pac. Bus. Rev. 2009, 15, 527-545. [CrossRef]

59. Pennings, J.M.; Barkema, H.; Douma, S. Organizational learning and diversification. Acad. Manag. J. 1994, 37, 608-640.

60. Sharma, A.; Kesner, I.F. Diversifying entry: Some ex ante explanations for postentry survival and growth. Acad. Manag. J. 1996, 39, 635-677.

61. Luo, Y. Product diversification in international joint ventures: Performance implications in an emerging market. Strateg. Manag. J. 2002, 23, 1-20. [CrossRef]

62. Levitt, B.; March, J.G. Organizational Learning. Annu. Rev. Sociol. 1988, 14, 319-338. [CrossRef]

63. Tripsas, M.; Gavetti, G. Capabilities, cognition, and inertia: Evidence from digital imaging. Strateg. Manag. J. 2000, 21, 1147-1162. [CrossRef]

64. Johanson, J.; Vahlne, J.E. The international process of the firm: A model of knowledge development and increasing foreign commitment. J. Int. Bus. Stud. 1977, 8, 23-32. [CrossRef]

65. Collins, J.; Holcomb, T.; Certoc, T.; Hitt, M.A.; Lester, R. Learning by doing: Cross-border mergers and acquisitions. J. Bus. Res. 2009, 62, 1329-1334. [CrossRef]

66. Nadolska, A.; Barkema, H.G. Learning to internationalize: The pace and success of foreign acquisitions. J. Int. Bus. Stud. 2007, 38, 1170-1186. [CrossRef] 
67. Gaur, A.S.; Lu, J.W. Ownership strategies and survival of foreign subsidiaries: Impacts of institutional distance and experience. J. Manag. 2007, 33, 84-110. [CrossRef]

68. Balakrishnan, S.; Korza, M. Information asymmetry, adverse selection and joint ventures: Theory and evidence. J. Econ. Behav. Organ. 1993, 20, 9-117. [CrossRef]

69. Ghemawat, P. Distance still matters: The hard reality of global expansion. Harward Bus. Rev. 2001, 79, 137-147.

70. Clarke, J.E.; Tamaschke, R.; Liesch, P.W. International experience in international business research: A conceptualization and exploration of key themes. Int. J. Manag. Rev. 2013, 15, 265-279. [CrossRef]

71. Angwin, D. Mergers and acquisitions across European borders: National perspectives on preacquisition due diligence and the use of professional advisers. J. World Bus. 2001, 36, 32-57. [CrossRef]

72. House, R.J.; Hanges, P.J.; Javidan, M.; Dorfman, P.W.; Gupta, V. (Eds.) Culture, Leadership, and Organizations: The GLOBE Study of 62 Societies; Sage Publicaons: Thousand Oaks, CA, USA, 2014.

73. Chakrabarti, R.V.; Gupta-Mukherjee, S.; Jayaraman, N. Mars-Venus marriages: Culture and cross-border M\&A. J. Int. Bus. Stud. 2009, 40, 216-236.

74. Stahl, G.K.; Voigt, A. Do cultural differences matter in mergers and acquisitions? A tentative model and examination. Organ. Sci. 2008, 19, 160-176. [CrossRef]

75. Buono, P.J.; Bowditch, J.L.; Lewis, J.W. When Cultures Collide: The Anatomy of a Merger. Hum. Relat. 1985, 38, 477-500. [CrossRef]

76. Datta, D.K.; Puia, G. Cross-border acquisitions: An examination of the influence of relatedness and cultural fit on shareholder value creation in U.S. acquiring firms. Manag. Int. Rev. 1995, 35, 337-359.

77. Shimizu, K.; Hitt, M.A.; Vaidyanath, D.; Pisano, V. Theoretical foundations of cross-border mergers and acquisitionsA review of current research and recommendations for the future. J. Int. Manag. 2004, 10, 307-353. [CrossRef]

78. Chakrabarti, A.; Mitchell, W. The persistent effect of geographic distance in acquisition target selection. Organ. Sci. 2013, 24, 1805-1826. [CrossRef]

79. Dicken, P. Some aspects of decision making behavior of business organizations. Econ. Geogr. 1971, 47, 426-437. [CrossRef]

80. Popli, M.; Akbar, M.; Kumas, V.; Gaur, A. Reconceptualizing Cultural Distance: The Role of Cultural Experience Reserve in Cross-Border Acquisitions. J. World Bus. 2016, 51, 404-412. [CrossRef]

81. Barkema, H.G.; Vermeulen, F. What differences in the cultural backgrounds of partners are detrimental for international joint ventures? J. Int. Bus. Stud. 1997, 28, 845-864. [CrossRef]

82. Peng, G.Z.; Beamish, P.W. The effect of host country long term orientation on subsidiary ownership and survival. Asia Pac. J. Manag. 2014, 31, 423-453. [CrossRef]

83. Wang, H.; Schaan, J.L. How much distance do we need? Revisiting the national cultural distance paradox. Manag. Int. Rev. 2008, 48, 263-278. [CrossRef]

84. Moschier, C.; Campa, J.M. The European M\&A Industry: A Market in the Process of Construction. Acad. Manag. Perspect. 2009, 23, 71-87.

85. Prometeia. L'impatto Delle Acquisizioni All'Estero Sulle Performance Delle Imprese Italiane; Prometeia spa: Milano, Italy, 2014.

86. Bianco, M.; Casavola, P. Italian corporate governance: Effects on financial structure and firm performance. Eur. Econ. Rev. 1999, 43, 1057-1069. [CrossRef]

87. Faccio, M.; Lang, L.H. The ultimate ownership of Western European corporations. J. Financ. Econ. 2002, 65, 365-395. [CrossRef]

88. Staglianò, R.; La Rocca, M.; La Rocca, T. Agency costs of free cash flow, internal capital markets and unrelated diversification. Rev. Manag. Sci. 2014, 8, 145-174. [CrossRef]

89. ICE-ISTAT. L'Italia Nell'Economia Internazionale; Annual Report 2018-2019; Istituto Nazionale di Statistica: Rome, Italy, 2019.

90. UNCTAD. World Investment; Report 2016-Investor Nationality: Policy Challenges; United Nations Publication: Geneva, Switzerland, 2016.

91. Cerved. Osservatorio Fallimenti, Procedure e Chiusure d'Imprese; Cerved Group spa: Milano, Italy, 2020; Volume 41. 
92. Haleblian, J.; Kim, J.Y.; Rajagopalan, N. The Influence of Acquisition Experience and Performance on Acquisition Behavior: Evidence from the US Commercial Banking Industry. Acad. Manag. J. 2006, 49, 357-370. [CrossRef]

93. World Bank Group. Economy Profile Italy; Doing Business Report; The World Bank: Washington, DC, USA, 2020.

94. Moliterno, T.P.; Wiersema, M.F. Firm performance, rent appropriation, and the strategic resource divestment capability. Strateg. Manag. J. 2007, 28, 1065-1087. [CrossRef]

95. Montgomery, C.A.; Thomas, A.R. Divestment: Motives and gains. Strateg. Manag. J. 1988, 93-97. [CrossRef]

96. Hoskisson, R.E.; Eden, L.; Lau, C.M.; Wright, M. Strategy in emerging economies. Acad. Manag. J. 2000, 43, 249-267.

97. Hofstede, G. Culture's Consequences: International Differences in Work Related Values; Sage: Beverly Hills, CA, USA, 1980.

98. Hofstede, G. Culture's Consequences: Comparing Values, Behaviours, Institutions, and Organisations across Nations, 2nd ed.; Sage: Thousand Oaks, CA, USA, 2001.

99. Hitt, M.A.; Hoskisson, R.; Kim, H. International diversification: Effects on innovation and firm performance in product-diversified firms. Acad. Manag. 1997, 40, 767-798.

100. Harzing, A.W. Acquisitions versus greenfield investments: International strategy and management of entry modes. Strateg. Manag. J. 2002, 23, 211-227. [CrossRef]

101. Hashai, N.; Delios, A. Balancing growth across geographic diversification and product diversification: A contingency approach. Int. Bus. Rev. 2012, 21, 1052-1064. [CrossRef]

102. Mukherji, A. The relationship between prior performance and diversification: A study of three industries. Manag. Decis. 1998, 36, 180-188. [CrossRef]

103. Martin, J.D.; Sayrak, A. Corporate diversification and shareholder value: A survey of recent literature. J. Corp. Financ. 2003, 9, 37-57. [CrossRef]

104. Wang, L.; Zajac, E. Alliance or acquisition? A dyadic perspective on interfirm resource combinations. Strateg. Manag. J. 2007, 28, 1291-1317. [CrossRef]

105. Gooris, J.; Peeters, C. Home-host country distance in offshore governance choices. J. Int. Manag. 2014, 20, 73-86. [CrossRef]

106. Anand, J.; Delios, A. Location specificity and the transferability of downstream assets to foreign subsidiaries. J. Int. Bus. Stud. 1997, 28, 579-603. [CrossRef]

107. Fey, C.F.; Beamish, P.W. Organizational climate similarity and performance: International joint ventures in Russia. Organ. Stud. 2001, 22, 853-882. [CrossRef]

108. Kimberly, J.R. Organizational size and the structuralist perspective: A review, critique, and proposal. Adm. Sci. Q. 1976, 571-597. [CrossRef]

109. Chen, M.J.; Hambrick, D.C. Speed, stealth, and selective attack: How small firms differ from large firms in competitive behavior. Acad. Manag. J. 1995, 38, 453-482. [CrossRef]

110. Zaheer, S. The liability of foreignness, redux: A commentary. J. Int. Manag. 2002, 8, 351-358. [CrossRef]

111. Weber, Y.; Shenkar, O.; Raveh, A. National and corporate cultural fit in mergers/acquisitions: An exploratory study. Manag. Sci. 1996, 42, 1215-1227. [CrossRef]

112. Schoenberg, R. The influence of cultural compatibility within cross-border acquisitions: A review. Adv. Mergers Acquis. 2000, 1, 43-59.

113. Shenkar, O. Cultural distance revisited: Towards a more rigorous conceptualization and measurement of cultural differences. J. Int. Bus. Stud. 2001, 32, 519-535. [CrossRef]

(C) 2020 by the authors. Licensee MDPI, Basel, Switzerland. This article is an open access article distributed under the terms and conditions of the Creative Commons Attribution (CC BY) license (http://creativecommons.org/licenses/by/4.0/). 